\title{
Immediate and Delayed Mortality of Four Stored-Product Pests on Concrete Surfaces Treated with Chlorantraniliprole
}

\author{
Nickolas G. Kavallieratos ${ }^{1, * \mathbb{D}}$, Maria C. Boukouvala ${ }^{1, *}$, Erifili P. Nika ${ }^{1}$, Nikoleta Eleftheriadou ${ }^{2}$ \\ and Dimitrios N. Avtzis ${ }^{2}$ (D) \\ 1 Laboratory of Agricultural Zoology and Entomology, Department of Crop Science, \\ Agricultural University of Athens, 75 Iera Odos Str., 11855 Athens, Attica, Greece; erifilinika@aua.gr \\ 2 Forest Research Institute, Hellenic Agricultural Organization Demeter, 57006 Vassilika, Thessalonıki, Greece; \\ eleftheria6363@gmail.com (N.E.); dimitrios.avtzis@fri.gr (D.N.A.) \\ * Correspondence: nick_kaval@aua.gr (N.G.K.); mbouk@aua.gr (M.C.B.); Tel.: +30-2105294569 (N.G.K.)
}

check for

updates

Citation: Kavallieratos, N.G.; Boukouvala, M.C.; Nika, E.P.; Eleftheriadou, N.; Avtzis, D.N. Immediate and Delayed Mortality of Four Stored-Product Pests on Concrete Surfaces Treated with Chlorantraniliprole. Insects 2021, 12, 1088. https://doi.org/10.3390/ insects12121088

Academic Editor: David Schlipalius

Received: 8 November 2021

Accepted: 1 December 2021

Published: 4 December 2021

Publisher's Note: MDPI stays neutral with regard to jurisdictional claims in published maps and institutional affiliations.

Copyright: (c) 2021 by the authors. Licensee MDPI, Basel, Switzerland. This article is an open access article distributed under the terms and conditions of the Creative Commons Attribution (CC BY) license (https:/ / creativecommons.org/licenses/by/ $4.0 /)$.
Simple Summary: We examined the mortality caused by the anthranilic diamide, chlorantraniliprole, at four different doses applied on concrete $\left(0.01,0.05,0.1\right.$, and $0.5 \mathrm{mg}$ a.i. $\left./ \mathrm{cm}^{2}\right)$ in Tribolium castaneum (Herbst) (Coleoptera: Tenebrionidae) adults and larvae, Rhyzopertha dominica (F.) (Coleoptera: Bostrychidae) adults, Sitophilus oryzae (L.) (Coleoptera: Curculionidae) adults, and Acarus siro L. (Sarcoptiformes: Acaridae) adults and nymphs. Mortality data were recorded after 1, 2, 3, 4, and 5 days to determine the immediate mortality. Furthermore, after the 5-day mortality counts, still living individuals were conveyed for 7 days to untreated concrete surfaces to estimate the delayed mortality. The highest immediate mortality was recorded for the larvae of $T$. castaneum, reaching $96.7 \%$, followed by the adults of $A$. siro $(92.2 \%)$ after 5 days of exposure to $0.5 \mathrm{mg}$ a.i. $/ \mathrm{cm}^{2}$. Complete (100.0\%) delayed mortality was noticed for T. castaneum (adults and larvae), S. oryzae, and A. siro (both as adults) at $0.5 \mathrm{mg}$ a.i. $/ \mathrm{cm}^{2}$. Rhyzopertha dominica adults and $A$. siro nymphs exhibited $98.6 \%$ and $96.3 \%$ delayed mortality at the same dose, respectively. Overall, our results demonstrate that chlorantraniliprole is effective against all the species tested, causing varying immediate and delayed mortality rates at the developmental stages tested.

Abstract: Chlorantraniliprole is an effective pesticide against a plethora of pests, but its efficacy against stored-product pests is very poorly explored. In this study we treated concrete surfaces with four different doses of chlorantraniliprole $\left(0.01,0.05,0.1\right.$, and $0.5 \mathrm{mg}$ a.i. $\left./ \mathrm{cm}^{2}\right)$ against the red flour beetle, Tribolium castaneum (Herbst) (Coleoptera: Tenebrionidae) adults and larvae, the lesser grain borer, Rhyzopertha dominica (F.) (Coleoptera: Bostrychidae) adults, the rice weevil, Sitophilus oryzae (L.) (Coleoptera: Curculionidae) adults, and the flour mite, Acarus siro L. (Sarcoptiformes: Acaridae) adults and nymphs, to examine the immediate mortalities after 1, 2, 3, 4, and 5 days of exposure. Additionally, the delayed mortality of the individuals that survived the 5-day exposure was also evaluated after a further 7 days on untreated concrete surfaces. We documented high mortality rates for all tested species and their developmental stages. After 5 days of exposure to $0.5 \mathrm{mg}$ a.i. $/ \mathrm{cm}^{2}$, T. castaneum larvae and A. siro adults exhibited the highest immediate mortality levels, reaching $96.7 \%$ and $92.2 \%$, respectively. Delayed mortality was also very high for all tested species and their developmental stages. Nymphs of $A$. siro displayed a $96.3 \%$ delayed mortality followed by the adults of $R$. dominica (98.6\%) after exposure to $0.5 \mathrm{mg}$ a.i. $/ \mathrm{cm}^{2}$. All other tested species and their developmental stages reached complete $(100.0 \%)$ delayed mortality, where even $0.01 \mathrm{mg}$ a.i. $/ \mathrm{cm}^{2}$ caused $\geq 86.6 \%$ delayed mortality in all species and their developmental stages. Taking into consideration the effectiveness of chlorantraniliprole on this wide range of noxious arthropods, coupled with its low toxicity towards beneficial arthropods and mammals, this pesticide could provide an effective management tool for stored-product pests in storage facilities.

Keywords: anthranilic diamide; concrete surface; insect; mite; pests 


\section{Introduction}

The red flour beetle, Tribolium castaneum (Herbst) (Coleoptera: Tenebrionidae) is a serious insect pest of high economic importance, infesting several stored cereals and foodstuffs worldwide [1]. It is a secondary pest commonly found in mills, warehouses, grocery stores, bakeries, and pet stores [2-5]. The lesser grain borer, Rhyzopertha dominica (F.) (Coleoptera: Bostrychidae) seems to have been originally feeding on dried fruits and forest trees [6], and it is currently identified as one of the most destructive insect pests of stored products globally $[2,6,7]$. As a primary pest, its larvae and adults can attack the sound kernels in storage facilities, while it can occasionally infect ripe grains in the field [8]. The rice weevil, Sitophilus oryzae (L.) (Coleoptera: Curculionidae) is a major pest of stored products worldwide, capable of infesting a wide range of commodities such as wheat, maize, barley, sorghum, rye, oats, rice, millet, cottonseed, dallisgrass seed, vetch seed, beans, nuts, flour, pasta, and cassava $[2,6,8]$. As this species is an internal feeder and completes its entire development inside kernels [6], its larvae remain protected from contact insecticides applied on the external part of the grain [9]. The flour mite, Acarus siro L. (Sarcoptiformes: Acaridae) is the most significant mite, infesting mainly cereal products like flour and other commodities like cheese, hay, medicinal herbs, spices, baby food, and fishmeal $[8,10-12]$. It can be found worldwide in farms, warehouses, mills, and empty grain bins, tainting the products with a musty smell $[8,12]$. Based on the biological traits presented before, the successful management of these species is restrained by specific difficulties. For instance, several insecticides are not effective against $R$. dominica that has developed resistance to specific formulations (including phosphine) [7,13-19]. Similarly, S. oryzae has become resistant to many insecticides in different parts of the world [19,20], indicating that the management of this species in storage facilities requires special care. It is well documented that $T$. castaneum presents resistance to a wide spectrum of insecticides around the globe [20-24]. Finally, A. siro is resistant to numerous pesticides. For instance, etrimfos, pirimiphos-methyl, fenitrothion, and chlorpyrifos-methyl were not totally $(100 \%)$ efficient against $A$. siro individuals throughout a 36-week-long trial [25], while, similarly, beta-cyfluthrin, deltamethrin, chlorpyrifos, and a mix of s-bioallethrin and deltamethrin did not result in killing A. siro individuals after 21 days of exposure [26]. Acarus siro can survive the exposure to diatomaceous earth (DE), such as $3 \mathrm{~g} / \mathrm{kg}$ Dryacide, from a sample taken from the surface of the bins, for up to 40 weeks [27]. As it becomes evident, the need to examine and find new alternative insecticidal active ingredients against these stored-product pests is imperative.

Chlorantraniliprole is a novel insecticide that belongs to the chemical group of anthranilic diamides [28,29]. It has a unique mode of action, activating the ryanodine receptor in insects' muscles and releasing the cellular calcium that causes the termination of feeding, increased lethargy, the paralysis of muscles, eventually leading to death [29-32]. In addition, chlorantraniliprole presents low mammalian toxicity and can kill a wide range of insect pests without harming beneficial arthropods [30,31,33,34]. For instance, it is very effective against species of agricultural importance belonging to different orders, e.g., Coleoptera, Lepidoptera, Hemiptera, Diptera, Isoptera, and Thysanoptera [35-41]. Furthermore, recent studies have verified the insecticidal activity of chlorantraniliprole applied on different commodities (i.e., barley, maize, oats, peeled rice, whole rice, and wheat) against the Mediterranean flour moth, Ephestia kuehniella Zeller (Lepidoptera: Pyralidae), the psocid, Liposcelis bostrychophila Badonnel (Psocoptera: Liposcelididae), R. dominica, S. oryzae, and the confused flour beetle, Tribolium confusum Jacquelin du Val (Coleoptera: Tenebrionidae) [42], or on maize against the larger grain borer, Prostephanus truncatus (Horn) (Coleoptera: Bostrychidae) [43]. However, there is limited knowledge about the efficacy of chlorantraniliprole applied on surfaces against stored-product pests. For example, this compound was examined as a surface treatment on concrete against the different life stages (i.e., eggs, young and old larvae, pupae and adults) of T. confusum [44]. Therefore, the objective of the present study is to simultaneously evaluate the immediate and delayed mortality of chlorantraniliprole applied on concrete surfaces against four important stored- 
product pests, i.e., T. castaneum adults and larvae, S. oryzae adults, $R$. dominica adults, and A. siro adults and nymphs.

\section{Materials and Methods}

\subsection{Insect and Mite Species}

The insect species used in the bioassays were obtained from colonies maintained under laboratory conditions since 2003. Tribolium castaneum was cultured on wheat flour containing $5 \%$ brewer's yeast at $25{ }^{\circ} \mathrm{C}$ and at $65 \%$ relative humidity in continuous darkness [45]. Adults of this species were $<2$ weeks old and larvae were 3rd-4th instar [46]. Rhyzopertha dominica and $S$. oryzae were reared on whole wheat at $25{ }^{\circ} \mathrm{C}$ at $65 \%$ relative humidity, and $<2$-week-old adults of these species were examined [47]. The initial population of A. siro was collected from wheat in Greek storage facilities in 2004, and since then it has been reared under laboratory conditions. The $A$. siro rearing medium consisted of a mixture of oat flakes, wheat germ, and the extract of dried yeast at a 10:10:1 w/w ratio. The colonies were kept at $25{ }^{\circ} \mathrm{C}$ and at $80 \%$ relative humidity. For the tests, the nymphs and adults of A. siro were selected according to their external morphology, i.e., the bodies of adults are larger and bear longer hairs than the bodies of nymphs [48]. All the above species were reared in continuous darkness.

\subsection{Insecticidal Formulation}

The formulation of chlorantraniliprole, Coragen ${ }^{\circledR}$ SC (suspension concentrate) with a $200 \mathrm{~g} / \mathrm{L}$ active ingredient a.i., which was provided by Dupont (Halandri, Greece), was used in the experiments.

\subsection{Bioassays}

Chlorantraniliprole was examined at four doses: $0.01,0.05,0.1$, and $0.5 \mathrm{mg}$ a.i. $/ \mathrm{cm}^{2}$. The experiments were carried out in a completely randomized block design, with three replicates and three subreplicates. Petri dishes that were $8 \mathrm{~cm}$ in diameter and $1.5 \mathrm{~cm}$ high, with a surface area of $50.27 \mathrm{~cm}^{2}$ each, were used. The concrete surface was made one day before the beginning of the tests by filling the bottoms of the Petri dishes with the CEM I $52.5 \mathrm{~N}$ material (Durostick, Aspropyrgos, Greece). To prevent the escape of the exposed individuals, the upper internal walls of all dishes were covered with polytetrafluoroethylene (60 wt\% dispersion in water) (Sigma-Aldrich Chemie $\mathrm{GmbH}$, Taufkirchen, Germany).

Spraying was conducted with the use of an AG-4 airbrush (Mecafer S.A., Valence, France), where $1 \mathrm{~mL}$ of an aqueous solution that contained the appropriate volume of the formulation corresponding to each dose was applied on concrete surface as a fine mist. The airbrush was cleaned with acetone after the spraying of each dose. A quantity of $0.5 \mathrm{~g}$ clean and pesticide-free whole wheat kernels without infestation was placed on each concrete surface after spraying, as food, for R. dominica, S. oryzae, and A. siro. For T. castaneum, the same quantity of soft white wheat flour (a variety mixture made from the endosperm only) was used in the experiments. An additional series of dishes were prepared and sprayed with distilled water ( $1 \mathrm{~mL}$ per dish) with a different AG-4 airbrush, as described above, to serve as controls. Subsequently, 10 individuals were transferred into each dish, and all dishes were put inside incubators set at $25{ }^{\circ} \mathrm{C}$ and at $65 \%$ relative humidity in continuous darkness. Mortality was determined under an Olympus stereomicroscope (Olympus SZX9, Bacacos S.A., Athens, Greece) after 1, 2, 3, 4, and 5 days of exposure in the treated dishes. After the 5th day of exposure, surviving individuals of each treated or untreated dish were transferred to new unsprayed concrete surfaces that also contained the same quantity of food for each species. The dishes were transferred again into the incubators with the same conditions for an additional period of 7 days. After this interval, the new dishes were opened and the number of the dead individuals per dish was counted, as described above. 


\subsection{Data Analysis}

For all tested species, the immediate or delayed mortality of the controls was low $(<5 \%)$, so no correction was considered necessary. The repeated measures model was used to separately analyze data for the immediate mortality of each tested species and developmental stage [49]. The repeated factor was the exposure interval, while mortality was the response variable. The dose was the main effect. Data for delayed mortality were submitted to a two-way ANOVA, with the species/developmental stage and dose as the main effects. The associated interaction of the main effects was also considered in the analysis. Prior to the analysis, the transformation of data to a $\log (x+1)$ scale was carried out in order to normalize the variance [50,51]. Means were separated by the Tukey-Kramer honest significant difference (HSD) test at the 0.05 significance level [52]. All analyses were conducted using the JMP 14 software [53].

\section{Results}

\subsection{Immediate Mortality}

Between and within the exposure intervals, all main effects were significant for all tested species and life stages, except for $R$. dominica adults (Table 1).

Table 1. MANOVA parameters for main effects and associated interaction for mortality of Tribolim castaneum adults and larvae, Sitophilus oryzae adults, Rhyzopertha dominica adults, and Acarus siro adults and nymphs between and within exposure intervals (error DF $=32$ ).

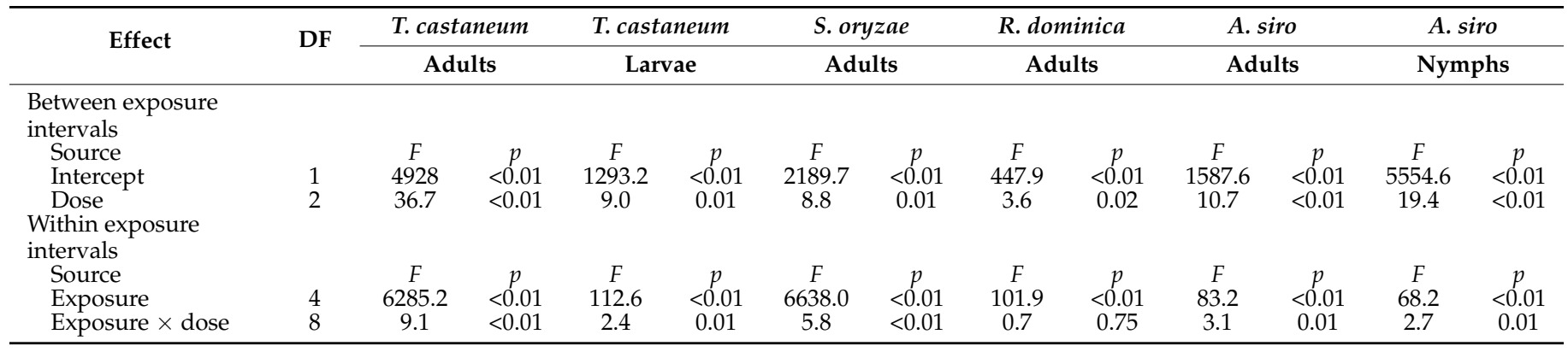

The mortality of $T$. castaneum adults was very low after 3 days of exposure in all tested doses and did not exceed $35.6 \%$ at $0.5 \mathrm{mg}$ a.i. $/ \mathrm{cm}^{2}$ (Table 2). Mortality increased further, reaching $56.7 \%$ at $0.5 \mathrm{mg}$ a.i. $/ \mathrm{cm}^{2}$, while at the other doses it ranged between $30.0 \%$ and $44.4 \%$ after 4 days of exposure. One day later, chlorantraniliprole killed $81.1 \%$ of the exposed adults at the highest dose $\left(0.5 \mathrm{mg}\right.$ a.i. $\left./ \mathrm{cm}^{2}\right)$ while it caused moderate mortality at the lower doses (i.e., $0.01,0.05$, and $0.1 \mathrm{mg}$ a.i. $/ \mathrm{cm}^{2}$ ), ranging from $42.2 \%$ to $61.1 \%$.

After 2 days of exposure, the mortality of T. castaneum larvae remained at low levels, reaching 33.3\% mortality (Table 3). One day later, mortality increased further, ranging between $21.1 \%$ and $37.8 \%$ at $0.01,0.05$, and $0.1 \mathrm{mg}$ a.i. $/ \mathrm{cm}^{2}$, and $60.0 \%$ at $0.5 \mathrm{mg}$ a.i. $/ \mathrm{cm}^{2}$. After 4 days of exposure, mortality reached $77.8 \%$ at $0.5 \mathrm{mg}$ a.i. $/ \mathrm{cm}^{2}$, while at 0.05 and $0.1 \mathrm{mg}$ a.i. $/ \mathrm{cm}^{2}$, it was moderate $(48.9 \%$ and $58.9 \%$, respectively). After 5 days of exposure, chlorantraniliprole killed almost all larvae $(96.7 \%)$ at $0.5 \mathrm{mg}$ a.i. $/ \mathrm{cm}^{2}$.

Regarding the immediate mortality of $S$. oryzae, after 3 days of exposure, it was very low at all tested doses and did not exceed $23.3 \%$ at $0.5 \mathrm{mg}$ a.i. $/ \mathrm{cm}^{2}$ (Table 4 ). The overall mortality did not exceed $45.6 \%$ after 4 days of exposure. At 5 days post-exposure, $80.0 \%$ of the exposed adults died on concrete treated with $0.5 \mathrm{mg}$ a.i. $/ \mathrm{cm}^{2}$, while mortality rates at all the other doses ranged between $45.6 \%$ and $71.1 \%$. 
Table 2. Mean immediate mortality ( $\% \pm$ SE) of Tribolium castaneum adults exposed on concrete treated with chlorantraniliprole at four doses $\left(0.01,0.05,0.1\right.$, and $0.5 \mathrm{mg}$ a.i. $\left./ \mathrm{cm}^{2}\right)$, for $1,2,3,4$, and 5 days. Within each row, means followed by the same uppercase letter are not significantly different (in all cases DF $=4,44$, Tukey-Kramer HSD test at $p=0.05$ ). Within each column, means that are followed by the same lower-case letter are not significantly different (in all cases DF $=3,35$, Tukey-Kramer HSD test at $p=0.05$ ). Where no letters exist, no significant differences were recorded. Where dashes exist, no analysis was performed.

\begin{tabular}{|c|c|c|c|c|c|c|c|}
\hline Exposure & 1 Day & 2 Days & 3 Days & 4 Days & 5 Days & $F$ & $p$ \\
\hline \multicolumn{8}{|c|}{ Dose (mg a.i./. $\left.\mathrm{cm}^{2}\right)$} \\
\hline 0.01 & $0.0 \pm 0.0 \mathrm{D}$ & $0.0 \pm 0.0 \mathrm{Db}$ & $12.2 \pm 1.5 \mathrm{Cc}$ & $30.0 \pm 1.7 \mathrm{Bc}$ & $42.2 \pm 2.8 \mathrm{Ac}$ & 1045.9 & $<0.01$ \\
\hline 0.05 & $0.0 \pm 0.0 \mathrm{D}$ & $0.0 \pm 0.0 \mathrm{Db}$ & $18.9 \pm 2.0 \mathrm{Cb}$ & $36.7 \pm 3.3 \mathrm{Bbc}$ & $54.4 \pm 2.9 \mathrm{Ab}$ & 790.0 & $<0.01$ \\
\hline 0.1 & $0.0 \pm 0.0 \mathrm{C}$ & $2.2 \pm 1.5 \mathrm{Cb}$ & $28.9 \pm 3.1 \mathrm{Ba}$ & $44.4 \pm 2.9 \mathrm{ABab}$ & $61.1 \pm 3.1 \mathrm{Ab}$ & 132.0 & $<0.01$ \\
\hline 0.5 & $0.0 \pm 0.0 \mathrm{D}$ & $11.1 \pm 2.0 \mathrm{Ca}$ & $35.6 \pm 2.9 \mathrm{Ba}$ & $56.7 \pm 2.9 \mathrm{ABa}$ & $81.1 \pm 1.1 \mathrm{Aa}$ & 160.0 & $<0.01$ \\
\hline$F$ & - & 21.8 & 20.8 & 14.8 & 29.8 & & \\
\hline$p$ & - & $<0.01$ & $<0.01$ & $<0.01$ & $<0.01$ & & \\
\hline
\end{tabular}

Table 3. Mean immediate mortality ( $\% \pm$ SE) of Tribolium castaneum larvae exposed on concrete treated with chlorantraniliprole at four doses $\left(0.01,0.05,0.1\right.$, and $0.5 \mathrm{mg}$ a.i. $\left./ \mathrm{cm}^{2}\right)$ for $1,2,3,4$, and 5 days. Within each row, means followed by the same uppercase letter are not significantly different (in all cases DF $=4,44$, Tukey-Kramer HSD test at $p=0.05$ ). Within each column, means that are followed by the same lower-case letter are not significantly different (in all cases DF $=3,35$, Tukey-Kramer HSD test at $p=0.05$ ). Where no letters exist, no significant differences were recorded.

\begin{tabular}{|c|c|c|c|c|c|c|c|}
\hline Exposure & 1 Day & 2 Days & 3 Days & 4 Days & 5 Days & $F$ & $p$ \\
\hline \multicolumn{8}{|c|}{ Dose (mg a.i.//cm²) } \\
\hline 0.01 & $2.2 \pm 1.5 \mathrm{Cb}$ & $7.8 \pm 3.6 \mathrm{Cb}$ & $21.1 \pm 3.5 \mathrm{Bc}$ & $38.9 \pm 2.0 \mathrm{ABC}$ & $66.7 \pm 2.4 \mathrm{Ac}$ & 30.3 & $<0.01$ \\
\hline 0.05 & $5.6 \pm 1.8 \mathrm{Cab}$ & $13.3 \pm 3.3 \mathrm{BCab}$ & $26.7 \pm 2.9 \mathrm{ABbc}$ & $48.9 \pm 3.1 \mathrm{Abc}$ & $77.8 \pm 4.3 \mathrm{Abc}$ & 20.2 & $<0.01$ \\
\hline 0.1 & $8.9 \pm 2.6 \mathrm{Cab}$ & $22.2 \pm 4.0 \mathrm{BCa}$ & $37.8 \pm 5.2 \mathrm{ABb}$ & $58.9 \pm 5.1 \mathrm{Ab}$ & $84.4 \pm 4.8 \mathrm{Aab}$ & 15.1 & $<0.01$ \\
\hline 0.5 & $14.4 \pm 2.9 \mathrm{Ca}$ & $33.3 \pm 4.1 \mathrm{Ba}$ & $60.0 \pm 4.4 \mathrm{ABa}$ & $77.8 \pm 4.0 \mathrm{Aa}$ & $96.7 \pm 1.7 \mathrm{Aa}$ & 25.2 & $<0.01$ \\
\hline$F$ & 4.3 & 5.8 & 12.2 & 20.0 & 12.3 & & \\
\hline$p$ & 0.01 & 0.01 & $<0.01$ & $<0.01$ & $<0.01$ & & \\
\hline
\end{tabular}

Table 4. Mean immediate mortality ( $\% \pm \mathrm{SE}$ ) of Sitophilus oryzae adults exposed on concrete treated with chlorantraniliprole at four doses $\left(0.01,0.05,0.1\right.$, and $0.5 \mathrm{mg}$ a.i. $\left./ \mathrm{cm}^{2}\right)$, for $1,2,3,4$, and 5 days. Within each row, means followed by the same uppercase letter are not significantly different (in all cases DF $=4,44$, Tukey-Kramer HSD test at $p=0.05$ ). Within each column, means that are followed by the same lower-case letter are not significantly different (in all cases DF $=3,35$, Tukey-Kramer HSD test at $p=0.05$ ). Where no letters exist, no significant differences were recorded. Where dashes exist, no analysis was performed.

\begin{tabular}{|c|c|c|c|c|c|c|c|}
\hline Exposure & 1 Day & 2 Days & 3 Days & 4 Days & 5 Days & $F$ & $p$ \\
\hline \multicolumn{8}{|c|}{ Dose (mg a.i./ $\left.\mathrm{cm}^{2}\right)$} \\
\hline 0.01 & $0.0 \pm 0.0 \mathrm{C}$ & $0.0 \pm 0.0 \mathrm{Cb}$ & $8.9 \pm 2.0 \mathrm{~B}$ & $25.6 \pm 2.9 \mathrm{Ab}$ & $45.6 \pm 3.8 \mathrm{Ac}$ & 96.4 & $<0.01$ \\
\hline 0.05 & $0.0 \pm 0.0 \mathrm{D}$ & $0.0 \pm 0.0 \mathrm{Db}$ & $15.6 \pm 1.8 \mathrm{C}$ & $30.0 \pm 5.3 \mathrm{Bb}$ & $62.2 \pm 2.8 \mathrm{Ab}$ & 333.6 & $<0.01$ \\
\hline 0.1 & $0.0 \pm 0.0 \mathrm{C}$ & $0.0 \pm 0.0 \mathrm{Cb}$ & $18.9 \pm 4.8 \mathrm{~B}$ & $36.7 \pm 2.9$ Aab & $71.1 \pm 3.1 \mathrm{Aab}$ & 82.8 & $<0.01$ \\
\hline 0.5 & $0.0 \pm 0.0 \mathrm{D}$ & $3.3 \pm 1.7 \mathrm{Ca}$ & $23.3 \pm 2.4 \mathrm{~B}$ & $45.6 \pm 2.4 \mathrm{ABa}$ & $80.0 \pm 1.7 \mathrm{Aa}$ & 106.0 & $<0.01$ \\
\hline$F$ & - & 4.0 & 2.6 & 4.8 & 21.3 & & \\
\hline$p$ & - & 0.02 & 0.07 & 0.01 & $<0.01$ & & \\
\hline
\end{tabular}

After 4 days of exposure, the percentages of dead $R$. dominica adults was low for all tested doses, reaching $32.2 \%$ at $0.5 \mathrm{mg}$ a.i. $/ \mathrm{cm}^{2}$ (Table 5). One day later, mortality increased without significant differences among doses, ranging from $34.4 \%$ to $50.0 \%$. 
Table 5. Mean immediate mortality ( $\% \pm \mathrm{SE}$ ) of Rhyzopertha dominica adults exposed on concrete treated with chlorantraniliprole at four doses $\left(0.01,0.05,0.1\right.$, and $0.5 \mathrm{mg}$ a.i. $\left./ \mathrm{cm}^{2}\right)$, for $1,2,3,4$, and 5 days. Within each row, means followed by the same uppercase letter are not significantly different (in all cases DF $=4,44$, Tukey-Kramer HSD test at $p=0.05$ ). Within each column, means that are followed by the same lower-case letter are not significantly different (in all cases DF $=3,35$, Tukey-Kramer HSD test at $p=0.05$ ). Where no letters exist, no significant differences were recorded.

\begin{tabular}{|c|c|c|c|c|c|c|c|}
\hline Exposure & 1 Day & 2 Days & 3 Days & 4 Days & 5 Days & $F$ & $p$ \\
\hline \multicolumn{8}{|c|}{ Dose (mg a.i./. $\left.\mathrm{cm}^{2}\right)$} \\
\hline 0.01 & $0.0 \pm 0.0 \mathrm{C}$ & $2.2 \pm 1.5 \mathrm{BC}$ & $7.8 \pm 2.8 \mathrm{~B}$ & $18.9 \pm 2.6 \mathrm{~A}$ & $34.4 \pm 3.8 \mathrm{Ab}$ & 29.8 & $<0.01$ \\
\hline 0.05 & $1.1 \pm 1.1 \mathrm{C}$ & $4.4 \pm 2.4 \mathrm{BC}$ & $8.9 \pm 2.6 \mathrm{~B}$ & $25.6 \pm 2.9 \mathrm{~A}$ & $40.0 \pm 4.1 \mathrm{Aab}$ & 22.0 & $<0.01$ \\
\hline 0.1 & $2.2 \pm 1.5 \mathrm{C}$ & $8.9 \pm 2.6 \mathrm{~B}$ & $15.6 \pm 2.4 \mathrm{AB}$ & $26.7 \pm 3.3 \mathrm{~A}$ & $43.3 \pm 2.4 \mathrm{Aab}$ & 22.9 & $<0.01$ \\
\hline 0.5 & $4.4 \pm 2.4 \mathrm{D}$ & $10.0 \pm 3.3 \mathrm{CD}$ & $16.7 \pm 4.1 \mathrm{BC}$ & $32.2 \pm 4.3 \mathrm{AB}$ & $50.0 \pm 4.1 \mathrm{Aa}$ & 13.2 & $<0.01$ \\
\hline$F$ & 1.4 & 2.2 & 2.6 & 2.2 & 3.1 & & \\
\hline$p$ & 0.25 & 0.11 & 0.07 & 0.11 & 0.04 & & \\
\hline
\end{tabular}

The mortality levels of $A$. siro adults was very low at doses $\leq 0.1 \mathrm{mg}$ a.i. $/ \mathrm{cm}^{2}$, reaching $38.9 \%$, while at $0.5 \mathrm{mg}$ a.i. $/ \mathrm{cm}^{2}$, moderate mortality was noted $(54.4 \%) 3$ days post-exposure (Table 6). One day later, mortality at $0.01 \mathrm{mg}$ a.i. $/ \mathrm{cm}^{2}$ remained at low levels $(38.9 \%)$, but at doses $\geq 0.1 \mathrm{mg}$ a.i. $/ \mathrm{cm}^{2}$, it ranged between $50.0 \%$ and $72.2 \%$. After 5 days of exposure, chlorantraniliprole killed $92.2 \%$ of the exposed adults at the highest dose, while at $0.01 \mathrm{mg}$ a.i. $/ \mathrm{cm}^{2}$, moderate mortality was recorded $(65.6 \%)$.

Table 6. Mean immediate mortality ( $\% \pm \mathrm{SE}$ ) of Acarus siro adults exposed on concrete treated with chlorantraniliprole at four doses $\left(0.01,0.05,0.1\right.$, and $0.5 \mathrm{mg}$ a.i. $\left./ \mathrm{cm}^{2}\right)$, for $1,2,3,4$, and 5 days. Within each row, means followed by the same uppercase letter are not significantly different (in all cases DF $=4,44$, Tukey-Kramer HSD test at $p=0.05$ ). Within each column, means that are followed by the same lower-case letter are not significantly different (in all cases DF $=3,35$, Tukey-Kramer HSD test at $p=0.05)$. Where no letters exist, no significant differences were recorded.

\begin{tabular}{|c|c|c|c|c|c|c|c|}
\hline Exposure & 1 Day & 2 Days & 3 Days & 4 Days & 5 Days & $F$ & $p$ \\
\hline \multicolumn{8}{|c|}{ Dose (mg a.i./cm²) } \\
\hline 0.01 & $0.0 \pm 0.0 \mathrm{Dc}$ & $7.8 \pm 2.2 \mathrm{Cb}$ & $24.4 \pm 3.4 \mathrm{Bb}$ & $38.9 \pm 3.5 \mathrm{ABC}$ & $65.6 \pm 2.9 \mathrm{Ac}$ & 67.7 & $<0.01$ \\
\hline 0.05 & $5.5 \pm 1.8 \mathrm{Cb}$ & $17.8 \pm 3.6 \mathrm{Bab}$ & $33.3 \pm 5.0 \mathrm{ABab}$ & $50.0 \pm 6.2 \mathrm{Abc}$ & $74.4 \pm 3.4 \mathrm{Abc}$ & 20.2 & $<0.01$ \\
\hline 0.1 & $10.0 \pm 1.7 \mathrm{Cab}$ & $27.8 \pm 4.3 \mathrm{BCa}$ & $38.9 \pm 4.6 \mathrm{ABab}$ & $62.2 \pm 4.7 \mathrm{Aab}$ & $82.2 \pm 2.8 \mathrm{Aab}$ & 14.5 & $<0.01$ \\
\hline 0.5 & $17.8 \pm 3.2 \mathrm{Ca}$ & $35.6 \pm 6.7 \mathrm{BCa}$ & $54.4 \pm 7.5 \mathrm{ABa}$ & $72.2 \pm 5.5 \mathrm{Aa}$ & $92.2 \pm 2.2 \mathrm{Aa}$ & 13.4 & $<0.01$ \\
\hline$F$ & 14.2 & 4.5 & 4.3 & 9.0 & 14.2 & & \\
\hline$p$ & $<0.01$ & 0.01 & 0.01 & 0.01 & $<0.01$ & & \\
\hline
\end{tabular}

Regarding $A$. siro nymphs, after 3 days of exposure, mortality was low at all tested doses, reaching $46.7 \%$ at $0.5 \mathrm{mg}$ a.i. $/ \mathrm{cm}^{2}$ (Table 7 ). Nymphal mortality ranged between $37.8 \%$ and $61.1 \%$ at 4 days post-exposure. Moderate mortality was recorded at doses $\geq 0.05 \mathrm{mg}$ a.i. $/ \mathrm{cm}^{2}$, reaching $73.3 \%$ at $0.5 \mathrm{mg}$ a.i. $/ \mathrm{cm}^{2}$ after 5 days of exposure.

Table 7. Mean immediate mortality ( $\% \pm \mathrm{SE}$ ) of Acarus siro nymphs exposed on concrete treated with chlorantraniliprole at four doses $\left(0.01,0.05,0.1\right.$, and $0.5 \mathrm{mg}$ a.i. $\left./ \mathrm{cm}^{2}\right)$, for $1,2,3,4$, and 5 days. Within each row, means followed by the same uppercase letter are not significantly different (in all cases DF $=4,44$, Tukey-Kramer HSD test at $p=0.05$ ). Within each column, means that are followed by the same lower-case letter are not significantly different (in all cases DF $=3,35$, Tukey-Kramer HSD test at $p=0.05)$. Where no letters exist, no significant differences were recorded.

\begin{tabular}{|c|c|c|c|c|c|c|c|}
\hline Exposure & 1 Day & 2 Days & 3 Days & 4 Days & 5 Days & $F$ & $p$ \\
\hline \multicolumn{8}{|c|}{ Dose (mg a.i. $\left./ \mathrm{cm}^{2}\right)$} \\
\hline 0.01 & $2.2 \pm 1.5 \mathrm{Cb}$ & $17.8 \pm 2.2 \mathrm{Bc}$ & $27.8 \pm 3.2 \mathrm{ABb}$ & $37.8 \pm 2.2 \mathrm{Ac}$ & $45.6 \pm 3.4 \mathrm{Ac}$ & 53.2 & $<0.01$ \\
\hline 0.05 & $7.8 \pm 1.5 \mathrm{Ca}$ & $24.4 \pm 3.4 \mathrm{Bbc}$ & $38.9 \pm 3.9 \mathrm{ABab}$ & $47.8 \pm 3.6 \mathrm{ABbc}$ & $56.7 \pm 3.3 \mathrm{Abc}$ & 22.2 & $<0.01$ \\
\hline 0.1 & $13.3 \pm 1.7 \mathrm{Da}$ & $31.1 \pm 3.1 \mathrm{Cab}$ & $40.0 \pm 3.3 \mathrm{BCa}$ & $54.4 \pm 3.4 \mathrm{ABab}$ & $64.4 \pm 4.4 \mathrm{Aab}$ & 51.5 & $<0.01$ \\
\hline 0.5 & $16.7 \pm 1.7 \mathrm{Da}$ & $36.7 \pm 2.9 \mathrm{Ca}$ & $46.7 \pm 1.7 \mathrm{BCa}$ & $61.1 \pm 2.6 \mathrm{ABa}$ & $73.3 \pm 3.7 \mathrm{Aa}$ & 73.2 & $<0.01$ \\
\hline$F$ & 15.8 & 7.6 & 5.6 & 10.9 & 9.8 & & \\
\hline$p$ & $<0.01$ & 0.01 & 0.01 & $<0.01$ & 0.01 & & \\
\hline
\end{tabular}




\subsection{Delayed Mortality of the Tested Species}

The main effect dose was significant for all species (Table 8). Delayed mortality was high for T. castaneum adults, given that $>91.0 \%$ of the adults died on concrete treated with $0.01,0.05$, or $0.1 \mathrm{mg}$ a.i. $/ \mathrm{cm}^{2}$, while $100.0 \%$ was recorded at $0.5 \mathrm{mg}$ a.i. $/ \mathrm{cm}^{2}$ (Table 9). The same trend was noted for larval delayed mortality of this species. Complete mortality was noticed at $0.5 \mathrm{mg}$ a.i. $/ \mathrm{cm}^{2}$. Moreover, $100.0 \%$ delayed mortality was noted for S. oryzae adults at 0.1 and $0.5 \mathrm{mg}$ a.i. $/ \mathrm{cm}^{2}$. Rhyzopertha dominica adults reached $96.7 \%$ and $98.6 \%$ delayed mortality at 0.1 and $0.5 \mathrm{mg}$ a.i. $/ \mathrm{cm}^{2}$, respectively. Concerning A. siro, adults were more susceptible than nymphs. All adults died at 0.1 and $0.5 \mathrm{mg}$ a.i. $/ \mathrm{cm}^{2}$. However, $94.4 \%$ and $96.3 \%$ of the exposed nymphs died on concrete treated with 0.1 and $0.5 \mathrm{mg}$ a.i. $/ \mathrm{cm}^{2}$, respectively.

Table 8. ANOVA parameters for main effects and the associated interaction for delayed mortality of Tribolium castaneum adults and larvae, Sitophilus oryzae adults, Rhyzopertha dominica adults, and Acarus siro adults and nymphs (total DF $=202$ ).

\begin{tabular}{cccc}
\hline Effect & DF & \multicolumn{3}{c}{ Species } \\
\hline Source & & $\boldsymbol{F}$ & $\boldsymbol{p}$ \\
\hline Species & 5 & 1.5 & 0.21 \\
Dose & 3 & 8.1 & $<0.01$ \\
Species $\times$ dose & 15 & 0.4 & 1.00 \\
\hline
\end{tabular}

Table 9. Mean delayed mortality ( $\% \pm$ SE) of Tribolium castaneum adults and larvae, Sitophilus oryzae adults, Rhyzopertha dominica adults, and Acarus siro adults and nymphs exposed on concrete treated with chlorantraniliprole at four doses $\left(0.01,0.05,0.1\right.$, and $0.5 \mathrm{mg}$ a.i. $\left./ \mathrm{cm}^{2}\right)$. Within each row, means followed by the same lowercase letter are not significantly different (in all cases DF $=3,35$, Tukey-Kramer HSD test at $p=0.05$ ). Where no letters exist, no significant differences were recorded.

\begin{tabular}{|c|c|c|c|c|c|c|c|}
\hline Dose (mg a.i./. $\left.\mathrm{cm}^{2}\right)$ & 0.01 & 0.05 & 0.1 & 0.5 & DF & $F$ & $p$ \\
\hline \multicolumn{8}{|l|}{ Species/Life Stage } \\
\hline T. castaneum adults & $91.0 \pm 2.9$ & $95.4 \pm 3.1$ & $97.8 \pm 2.2$ & $100.0 \pm 0.0$ & 3,35 & 2.5 & 0.08 \\
\hline T. castaneum larvae & $88.0 \pm 4.2$ & $93.5 \pm 4.3$ & $97.2 \pm 2.8$ & $100.0 \pm 0.0$ & 3,25 & 1.2 & 0.32 \\
\hline S. oryzae adults & $97.8 \pm 2.2$ & $98.2 \pm 1.9$ & $100.0 \pm 0.0$ & $100.0 \pm 0.0$ & 3,35 & 0.7 & 0.58 \\
\hline R. dominica adults & $86.6 \pm 3.4 b$ & $92.6 \pm 2.6 \mathrm{ab}$ & $96.7 \pm 2.4 \mathrm{a}$ & $98.6 \pm 1.4 \mathrm{a}$ & 3,35 & 4.3 & 0.01 \\
\hline A. siro adults & $88.2 \pm 6.0$ & $92.6 \pm 4.9$ & $100.0 \pm 0.0$ & $100.0 \pm 0.0$ & 3,32 & 1.9 & 0.15 \\
\hline A. siro nymphs & $90.3 \pm 4.2$ & $92.6 \pm 3.8$ & $94.4 \pm 3.7$ & $96.3 \pm 3.7$ & 3,35 & 0.4 & 0.75 \\
\hline
\end{tabular}

\section{Discussion}

Our results indicate that chlorantraniliprole is a promising pesticide for the effective control of the adults and larvae of T. castaneum, the adults of S. oryzae and R. dominica, and the adults and nymphs of $A$. siro, when applied on concrete surfaces. In the present study, chlorantraniliprole killed $81.1 \%$ of $T$. castaneum adults, $96.7 \%$ of $T$. castaneum larvae, $80.0 \%$ of $S$. oryzae adults, $50.0 \%$ of $R$. dominica, $92.2 \%$ of $A$. siro adults, and $73.3 \%$ of $A$. siro nymphs after 5 days of exposure to 0.5 a.i. $/ \mathrm{cm}^{2}$. In a former study, Kavallieratos et al. [42] investigated the efficacy of two chlorantraniliprole formulations (WG and SC) as grain protectants against L. bostrychophila, R. dominica, S. oryzae adults, E. kuehniella larvae, and T. confusum adults and larvae. The $10 \mathrm{mg}$ a.i. $/ \mathrm{kg}$ of grain of the WG formulation killed $95.6 \%$ of S. oryzae adults after 7 days of exposure on treated whole rice, while at the same dose, the SC formulation caused the mortality of $99.4 \%$ exposed individuals. Both chlorantraniliprole formulations killed $100.0 \%$ of $S$. oryzae adults after 14 days of exposure to the $10 \mathrm{mg}$ a.i. $/ \mathrm{kg}$ of grain. Concerning $R$. dominica, the WG formulation at $10 \mathrm{mg}$ a.i. $/ \mathrm{kg}$ of grain killed $88.3 \%$ of the adults after 7 days of exposure and $100.0 \%$ after 14 days of exposure on whole rice and wheat, respectively. The SC chlorantraniliprole 
was also effective at causing $83.3 \%$ and $96.7 \%$ mortality rates 7 and 14 days post-exposure, respectively, to treated whole rice. Furthermore, both chlorantraniliprole formulations effectively controlled E. kuehniella larvae, L. bostrychophila adults, and T. confusum adults and larvae on several commodities (e.g., hard wheat, barley, maize, peeled rice, whole rice, and oats). Similarly, Saglam et al. [44] documented that $0.1 \mathrm{mg}$ a.i. $/ \mathrm{cm}^{2}$ sprayed on concrete killed $66 \%, 100.0 \%$, and $64 \%$ of $T$. confusum adults, young larvae, and old larvae, respectively. It also delayed the adult emergence on the first 5 days of the experiment. Chlorantraniliprole (WG and SC) is also effective as maize protectant against $P$. truncatus. In a recent study, Boukouvala and Kavallieratos [43] found that $10 \mathrm{mg}$ a.i. WG $/ \mathrm{kg}$ of grain and $10 \mathrm{mg}$ a.i. SC $/ \mathrm{kg}$ of grain killed $98.9 \%$ and $96.1 \%$ of the exposed individuals after 14 days of exposure, respectively, at $30{ }^{\circ} \mathrm{C}$. Although chlorantraniliprole is not yet authorized for the management of stored-product pests, the aforementioned findings are valuable inputs for its potential use. These research efforts are of particular importance as the number of registered plant protection products in stored-product protection is considerably reduced [54]. Therefore, chlorantraniliprole can be clasified as an a.i. that could potentially recieve registration to be used in storage facilities as a grain protectant and/or as a structural treatment.

Surface treatments constitute an effective approach for the management of storedproduct pests. To date, a plethora of pesticides have been applied onto several types of surfaces under different scenarios. For instance, when Kavallieratos et al. [55] treated polypropylene storage bags with alpha-cypermethrin, the immediate mortality of $R$. dominica and S. oryzae adults was $37.8 \%$ and $40.0 \%$ at 5 days post-exposure, respectively. Adults of T. castaneum that were exposed to plywood, tiles, and concrete treated with chlorfenapyr exhibited different levels of survival $(40.0 \%, 25.5 \%$, and $2.5 \%$, respectively), concluding that the type of the treated surface affects the efficacy of the tested formulation [56]. Similarly, Vassilakos et al. [57] evaluated ceramic tiles, plywood, concrete, and galvanized steel treated with spinetoram against T. confusum, S. oryzae, S. granarius, $R$. dominica, the rusty grain beetle, Cryptolestes ferrugineus (Stephens) (Coleoptera: Laemophloeidae), and Oryzaephilus surinamensis (L.) (Coleoptera: Silvanidae) adults. The different treated surfaces led to different mortality rates among all the exposed pests. For example, $0.05 \mathrm{mg}$ spinetoram $/ \mathrm{cm}^{2}$ killed $77.4 \%, 68.1 \%, 89.0 \%$, and $59.2 \%$ of $T$. confusum adults on ceramic tiles, plywood, concrete, and galvanized steel, respectively, at 7 days post-exposure. Furthermore, the mortality of E. kuehniella larvae caused by thiamethoxam, alpha-cypermethrin, and deltamethrin treated on woven polypropylene $\left(0.10 \mathrm{mg}\right.$ a.i. $\left./ \mathrm{cm}^{2}\right)$ ranged between $40.0 \%$ and $82.2 \%$ [58]. Our findings document that chlorantraniliprole caused even higher mortality rates than the aforementioned formulations in some of the stored-product pests, as in the cases of T. castaneum larvae and $A$. siro adults. The fact that chlorantraniliprole killed almost all young larvae of $T$. castaneum under the short exposure scenario followed in our study is of particular importance. This is because chlorantraniliprole can cause the rapid collapse of the larval population upon contact to treated concrete and can consequently prohibit the emergence of adults which, as flyers and walkers, easily colonize stored food commodities $[8,59,60]$. Whether chlorantraniliprole can perform similarly to the older larvae of T. castaneum merits further investigation. In an earlier study, Saglam et al. [44] showed that when the old larvae of $T$. confusum came into contact with concrete surfaces treated with chlorantraniliprole, they exhibited tolerance to this toxicant, taking into account that around $50 \%$ of larvae survived after 14 days of exposure. Our study provides new information about the management of $A$. siro on surface treatment, given that there is limited knowledge, mostly coming from previous decades. For example, the DEs SilicoSec and Diasecticide killed $28-98 \%$ and $64-88 \%$ of $A$. siro adults after $24 \mathrm{~h}$ of exposure to three slurry doses $\left(2.5,5\right.$, and $\left.10 \mathrm{~g} / \mathrm{m}^{2}\right)$ [61]. Although we obtained low mortality rates after $24 \mathrm{~h}$ of exposure with $A$. siro adults, $92.2 \%$ finally died 5 days post-exposure, which is also considered a short exposure interval.

In our study, the delayed mortality was extremely high, ranging between $96.3 \%$ and $100.0 \%$ in all tested species and their developmental stages. This is an important finding 
as it provides a plausible scenario of the arthropods moving from treated to untreated areas that may lead to their colonization by the pests [55,62-64]. This highly toxic effect of delayed mortality is also evident in the cases of several other pesticides. For instance, alpha-cypermethrin caused moderate-to-high delayed mortality in R. dominica (from 37.8\% to $46.7 \%$ ) and S. oryzae adults (from $32.2 \%$ to $60.0 \%$ ) [55]. Chlorfenapyr killed $56.7 \%$ of $S$. oryzae adults after being transferred onto untreated surfaces (polypropylene bags) [55]. As with immediate mortality, delayed mortality may differ depending on the surface that the pesticide is applied. For example, $0.1 \mathrm{mg}$ spinetoram $/ \mathrm{cm}^{2}$ killed $100.0 \%$ of $R$. dominica on concrete, but $97.0 \%$ on galvanised steel [57]. The presence of untreated food lowered the delayed mortality rates of S. oryzae adults from $100.0 \%$ to $98.8 \%$ and from $91.4 \%$ to $78.7 \%$ with the T. confusum adults [57]. In addition to the aforementioned parameters that affect the rates of delayed mortality, the species and the developmental stage of the exposed pest are equally important, something that was clearly demonstrated both in the current study and in previous investigations. For example, thiamethoxan killed 3.3\% of T. molitor adults and $35.6 \%$ of $T$. molitor large larvae, while the same pesticide killed $63.3 \%$ of $T$. granarium adults and $1.1 \%$ of $T$. granarium old larvae [62].

\section{Conclusions}

In conclusion, our study provides new data towards the efficacy of chlorantraniliprole on concrete at four doses against important arthropod pests of stored products. On the basis of our findings, chlorantraniliprole can be a useful management tool since it caused high levels of both immediate and delayed mortality to the majority of the tested species and their developmental stages. However, further experimentation is required to assess the efficacy of chlorantraniliprole applied on other types of surfaces (e.g., storage bags) under different environmental conditions (temperature and relative humidity), doses, exposure intervals, and other stored-product pests in conjunction with their egg laying capacities.

Author Contributions: Designed research, N.G.K.; methodology, N.G.K., M.C.B. and E.P.N.; investigation, N.G.K., M.C.B., E.P.N., N.E. and D.N.A.; data curation, N.G.K., M.C.B. and E.P.N. formal analysis, M.C.B. and N.G.K.; writing-original draft, N.G.K., M.C.B. and E.P.N.; writing-review and editing, N.G.K., M.C.B., E.P.N., N.E. and D.N.A.; supervision, N.G.K.; resources, N.G.K.; funding acquisition, N.G.K. All authors have read and agreed to the published version of the manuscript.

Funding: The research was partially funded by the 34.0889 project (Special Account for Research Funds of the Agricultural University of Athens).

Institutional Review Board Statement: Not applicable.

Data Availability Statement: Data are contained within the article.

Conflicts of Interest: The authors declare no conflict of interest.

\section{References}

1. Ridley, A.W.; Hereward, J.P.; Daglish, G.J.; Raghu, S.; Collins, P.J.; Walter, G.H. The spatiotemporal dynamics of Tribolium castaneum (Herbst): Adult flight and gene flow. Mol. Ecol. 2011, 20, 1635-1646. [CrossRef]

2. $\quad$ Aitken, A.D. Insect Travelers, I: Coleoptera. Technical Bulletin 31; H.M.S.O.: London, UK, 1975.

3. Hagstrum, D.W.; Subramanyam, B. Stored-Product Insect Resource; AACC International: St. Paul, MN, USA, 2009.

4. Mahroof, R.M.; Hagstrum, D.W. Biology, behavior, and ecology of insects in processed commodities. In Stored Product Protection; Hagstrum, D.W., Phillips, T.W., Cuperus, G., Eds.; Kansas State University: Manhattan, KS, USA, 2012; pp. 33-44.

5. Kumar, R. Insect Pests on Stored Grain. Biology, Behavior, and Management Strategies; Apple Academic Press: Waretown, NJ, USA, 2017.

6. Mason, L.J.; McDonough, M. Biology, behavior, and ecology of stored grain and legume insects. In Stored Product Protection; Hagstrum, D.W., Phillips, T.W., Cuperus, G., Eds.; Kansas State University: Manhattan, KS, USA, 2012; pp. 7-20.

7. Edde, P.A. A review of the biology and control of Rhyzopertha dominica (F.) the lesser grain borer. J. Stored Prod. Res. 2012, 48, 1-18. [CrossRef]

8. Hill, D.S. Pests of Stored Foodstuffs and Their Control; Kluwer Academic Publishers: New York, NY, USA, 2003.

9. Arthur, F.H.; Throne, J.E. Efficacy of diatomaceous earth to control internal infestations of rice weevil and maize weevil (Coleoptera: Curculionidae). J. Econ. Entomol. 2003, 96, 510-518. [CrossRef] 
10. Mullen, G.R.; OConnor, B.M. Mites (Acari). In Medical and Veterinary Entomology; Mullen, G.R., Durden, L.A., Eds.; Academic Press: London, UK, 2002; pp. 449-516.

11. Robinson, W.H. Urban Insects and Arachnids; Cambridge University Press: Cambridge, UK, 2005.

12. Hagstrum, D.W.; Klejdysz, T.; Subramanyam, B.; Nawrot, J. Atlas of Stored-Product Insects and Mites; AACC International: St. Paul, MN, USA, 2013.

13. Guedes, R.N.C.; Dover, B.A.; Kambhampati, S. Resistance to chlorpyrifosmethyl, pirimiphos-methyl, and malathion in Brazilian and U.S. populations of Rhyzopertha dominica (Coleoptera: Bostrichidae). J. Econ. Entomol. 1996, 89, 27-32. [CrossRef]

14. Lorini, I.; Galley, D.J. Deltamethrin resistance in Rhyzopertha dominica (F.) (Coleoptera: Bostrichidae), a pest of stored grain in Brazil. J. Stored Prod. Res. 1999, 35, 37-45. [CrossRef]

15. Collins, P.J.; Daglish, G.J.; Bengston, M.; Lambkin, T.M.; Pavic, H. Genetics of resistance to phosphine in Rhyzopertha dominica (Coleoptera: Bostrichidae). J. Econ. Entomol. 2002, 95, 862-869. [CrossRef] [PubMed]

16. Daglish, G.J. Impact of resistance on the efficacy of binary combinations of spinosad, chlorpyriphos-methyl and s-methoprene against five stored-grain beetles. J. Stored Prod. Res. 2008, 44, 71-76. [CrossRef]

17. Schlipalius, D.; Chen, W.; Collins, P.; Nguyen, T.; Reilly, P.; Ebert, P. Gene interactions constrain the course of evolution of phosphine resistance in the lesser grain borer, Rhyzopertha dominica. Heredity 2008, 100, 506-516. [CrossRef] [PubMed]

18. Athanassiou, C.G.; Arthur, F.H.; Kavallieratos, N.G.; Throne, J.E. Efficacy of spinosad and methoprene, applied alone or in combination, against six stored product insect species. J. Pest. Sci. 2011, 84, 61-67. [CrossRef]

19. Wakil, W.; Kavallieratos, N.G.; Usman, M.; Gulzar, S.; El-Shafie, H.A.F. Detection of phosphine resistance in field populations of four key stored-grain insect pests in Pakistan. Insects 2021, 12, 288. [CrossRef] [PubMed]

20. Attia, M.A.; Wahba, T.F.; Shaarawy, N.; Moustafa, F.I.; Guedes, R.N.C.; Dewer, Y. Stored grain pest prevalence and insecticide resistance in Egyptian populations of the red flour beetle Tribolium castaneum (Herbst) and the rice weevil Sitophilus oryzae (L.). J. Stored Prod. Res. 2020, 87, 101611. [CrossRef]

21. Halliday, W.R.; Arthur, E.H.; Zettler, J.L. Resistance status of red flour beetle (Coleoptera: Tenebrionidae) infesting stored peanuts in the southeastern United States. J. Econ. Entomol. 1988, 76, 717-722. [CrossRef]

22. Arthur, F.H. Grain protectants: Current status and prospects for the future. J. Stored Prod. Res. 1996, 32, 239-302. [CrossRef]

23. Stadler, T.; Subramanyam, B.; Ferrero, A.A. Monitoring for insecticide resistance in major stored product pests in Argentina: A review. Agriscientia 2003, 20, 99-110.

24. Rossi, E.; Cosimi, S.; Loni, A. Insecticide resistance in Italian populations of Tribolium flour beetles. Bull. Insectol. 2010, 63, 251-258.

25. Thomas, K.P.; Pinniger, D.B.; Wilkin, D.R. An assessment of chlorpyrifos-methyl, etrimfos, fenitrothion and pirimiphos-methyl as grain protectants. Pestic. Sci. 1987, 21, 57-72. [CrossRef]

26. Hubert, J.; Stejskal, V.; Munzbergova, Z.; Hajslova, J.; Arthur, F.H. Toxicity and efficacy of selected pesticides and new acaricides to stored product mites (Acari: Acaridida). Exp. Appl. Acarol. 2007, 42, 283-290. [CrossRef] [PubMed]

27. Cook, D.A.; Armitage, D.M. Efficacy of a diatomaceous earth against mite and insect populations in small bins of wheat under conditions of low temperature and high humidity. Pest Manag. Sci. 2000, 56, 591-596. [CrossRef]

28. Lahm, G.P.; Selby, T.P.; Freudenberger, J.H.; Stevenson, T.M.; Myers, B.J.; Seburyamo, G.; Smith, B.K.; Flexner, L.; Clark, C.E.; Cordova, D. Insecticidal anthranilic diamides: A new class of potent ryanodine receptor activators. Bioorg. Med. Chem. Lett. 2005, 15, 4898-4906. [CrossRef]

29. Cordova, D.; Benner, E.; Sacher, M.; Rauh, J.; Sopa, J.; Lahm, G.; Selby, T.; Stevenson, T.; Flexner, L.; Gutteridge, S.; et al. Anthranilic diamides: A new class of insecticides with a novel mode of action, ryanodine receptor activation. Pestic. Biochem. Physiol. 2006, 84, 196-214. [CrossRef]

30. Lahm, G.P.; Stevenson, T.M.; Selby, T.P.; Freudenberger, J.H.; Cordova, D.; Flexner, L.; Bellin, C.A.; Dubas, C.M.; Smith, B.K.; Hughes, K.A.; et al. Rynaxypyr ${ }^{\mathrm{TM}}$ : A new insecticidal anthranilic diamide that acts as a potent and selective receptor activator. Bioorg. Med. Chem. Lett. 2007, 17, 6274-6279. [CrossRef]

31. Lahm, G.P.; Cordova, D.; Barry, J.D. New and selective ryanodine receptor activators for insect control. Bioorg. Med. Chem. 2009, 17, 4127-4133. [CrossRef]

32. Sattelle, D.B.; Cordova, D.; Cheek, T.R. Insect ryanodine receptors: Molecular targets for novel pest control chemicals. Invertebr. Neurosci. 2008, 8, 107-119. [CrossRef] [PubMed]

33. Liu, F.; Zhang, X.; Gui, Q.Q.; Xu, Q.J. Sublethal effects of four insecticides on Anagrus nilaparvatae (Hymenoptera: Mymaridae), an important egg parasitoid of the rice planthopper Nilaparvata lugens (Homoptera: Delphacidae). Crop Prot. 2012, 37, 13-19. [CrossRef]

34. Nawaz, M.; Cai, W.; Jing, Z.; Zhou, X.; Mabubu, J.I.; Hua, H. Toxicity and sublethal effects of chlorantraniliprole on the development and fecundity of a non-specific predator, the multicolored Asian lady beetle, Harmonia axyridis (Pallas). Chemosphere 2017, 178, 496-503. [CrossRef] [PubMed]

35. Hummel, N.A.; Mészáros, A.; Ring, D.R.; Beuzelin, J.M.; Stout, M.J. Evaluation of seed treatment insecticides for management of the rice water weevil, Lissorhoptrus oryzophilus Kuschel (Coleoptera: Curculionidae), in commercial rice fields in Louisiana. Crop Prot. 2014, 65, 37-42. [CrossRef]

36. Plata Rueda, A.; Martínez, L.C.; Costa, N.C.R.; Zanuncio, J.C.; Fernandes, M.E.D.S.; Serrão, J.E.; Guedes, R.N.C.; Fernandes, F.L. Chlorantraniliprole-mediated effects on survival, walking abilities, and respiration in the coffee berry borer, Hypothenemus hampei. Ecotoxicol. Environ. Saf. 2019, 172, 53-58. [CrossRef] 
37. Teixeira, L.A.F.; Gut, L.J.; Wise, J.C.; Isaacs, R. Lethal and sublethal effects of chlorantraniliprole on three species of Rhagoletis fruit flies (Diptera: Tephritidae). Pest Manag. Sci. 2008, 65, 137-143. [CrossRef]

38. Liu, J.L.; Yang, X.; Chen, X.; Wu, J.C. Suppression of fecundity, Nlvg gene expression and vitellin content in Nilaparvata lugens Stål (Hemiptera: Delphacidae) adult females exposed to indoxacarb and chlorantraniliprole. Pestic. Biochem. Physiol. 2012, 104, 206-211. [CrossRef]

39. Neoh, K.B.; Hu, J.; Yeoh, B.H.; Lee, C.Y. Toxicity and horizontal transfer of chlorantraniliprole against the Asian subterranean termite Coptotermes gestroi (Wasmann): Effects of donor: Recipient ratio, exposure duration and soil type. Pest Manag. Sci. 2012, 68, 749-756. [CrossRef]

40. He, F.; Sun, S.; Tan, H.; Sun, X.; Qin, C.; Ji, S.; Li, X.; Zhang, J.; Jiang, X. Chlorantraniliprole against the black cutworm Agrotis ipsilon (Lepidoptera: Noctuidae): From biochemical/physiological to demographic responses. Sci. Rep. 2019, 9, 1-17.

41. Dale, A.G.; Borden, M.A. Evaluation of reduced-risk insecticides to control chilli thrips (Thysanoptera: Thripidae) and conserve natural enemies on ornamental plants. Fla. Entomol. 2018, 101, 237-243. [CrossRef]

42. Kavallieratos, N.G.; Athanassiou, C.G.; Boukouvala, M.C. Insecticidal effect of chlorantraniliprole against major stored-product insect pests in different grain commodities under laboratory tests. Pest Manag. Sci. 2013, 69, 1141-1154. [CrossRef] [PubMed]

43. Boukouvala, M.C.; Kavallieratos, N.G. Evaluation of two formulations of chlorantraniliprole as maize protectants for the management of Prostephanus truncatus (Horn) (Coleoptera: Bostrychidae). Insects 2021, 12, 194. [CrossRef]

44. Saglam, O.; Athanassiou, C.G.; Vassilakos, T.N. Comparison of spinetoram, imidacloprid, thiamethoxam and chlorantraniliprole against life stages of Tribolium confusum Jacquelin du Val (Coleoptera: Tenebrionidae) on concrete. Crop Prot. 2013, 53, 85-95. [CrossRef]

45. Athanassiou, C.G.; Kavallieratos, N.G.; Chiriloaie, A.; Vassilakos, T.N.; Fătu, V.; Drosu, S.; Ciobanu, M.; Dudoiu, R. Insecticidal efficacy of natural diatomaceous earth deposits from Greece and Romania against four stored grain beetles: The effect of temperature and relative humidity. Bull. Insectol. 2016, 69, 25-34.

46. Kavallieratos, N.G.; Nika, E.P.; Skourti, A.; Ntalli, N.; Boukouvala, M.C.; Ntalaka, C.T.; Maggi, F.; Rakotosaona, R.; Cespi, M.; Perinelli, D.R.; et al. Developing a Hazomalania voyronii essential oil nanoemulsion for the eco-friendly management of Tribolium confusum, Tribolium castaneum and Tenebrio molitor larvae and adults on stored wheat. Molecules 2021, 26, 1812. [CrossRef]

47. Kavallieratos, N.G.; Athanassiou, C.G.; Arthur, F.H. Effectiveness of insecticide-incorporated bags to control stored-product beetles. J. Stored Prod. Res. 2017, 70, 18-24. [CrossRef]

48. Hughes, A.M. The Mites of Stored Food and Houses. Technical Bulletin 9; H.M.S.O.: London., UK, 1976.

49. Sall, J.; Lehman, A.; Creighton, L. JMP start statistics. In A Guide to Statistics and Data Analysis Using JMP and JMP in Software; Duxbury Press: Belmont, ON, Canada, 2001.

50. Zar, J.H. Biostatistical Analysis; Pearson Education Limited: Essex, UK, 2014.

51. Scheff, D.S.; Arthur, F.H. Fecundity of Tribolium castaneum and Tribolium confusum adults after exposure to deltamethrin packaging. J. Pest Sci. 2018, 91, 717-725. [CrossRef]

52. Sokal, R.R.; Rohlf, F.J. Biometry; Freeman \& Company: New York, NY, USA, 1995.

53. SAS Institute Inc. Using JMP 14; SAS Institute Inc.: Cary, NC, USA, 2018.

54. Arthur, F.H. Efficacy of combinations of methoprene and deltamethrin as long-term commodity protectants. Insects $\mathbf{2 0 1 9}, \mathbf{1 0}, \mathbf{5 0 .}$ [CrossRef]

55. Kavallieratos, N.G.; Athanassiou, C.G.; Nika, E.P.; Boukouvala, M.C. Efficacy of alpha-cypermethrin, chlorfenapyr and pirimiphosmethyl applied on polypropylene bags for the control of Prostephanus truncatus (Horn), Rhyzopertha dominica (F.) and Sitophilus oryzae (L.). J. Stored Prod. Res. 2017, 73, 54-61. [CrossRef]

56. Arthur, F.H. Efficacy of chlorfenapyr against Tribolium castaneum and Tribolium confusum (Coleoptera: Tenebrionidae) adults exposed on concrete, vinyl tile, and plywood surfaces. J. Stored Prod. Res. 2008, 44, 145-151. [CrossRef]

57. Vassilakos, T.N.; Athanassiou, C.G.; Chloridis, A.S.; Dripps, J.E. Efficacy of spinetoram as a contact insecticide on different surfaces against stored-product beetle species. J. Pest Sci. 2014, 87, 485-494. [CrossRef]

58. Papanikolaou, N.E.; Kavallieratos, N.G.; Boukouvala, M.C.; Malesios, C. (Quasi)-binomial vs. Gaussian models to evaluate thiamethoxam, pirimiphos-methyl, alpha- cypermethrin and deltamethrin on different types of storage bag materials against Ephestia kuehniella Zeller (Lepidoptera: Pyralidae) and Tribolium confusum Jacquelin du Val (Coleoptera: Tenebrionidae). Insects 2021, 12, 182. [PubMed]

59. Perez Mendoza, J.; Campbell, J.F.; Throne, J.E. Effects of rearing density, age, sex, and food deprivation on flight initiation of the red flour beetle (Coleoptera: Tenebrionidae). J. Econ. Entomol. 2011, 104, 443-451. [CrossRef]

60. Perez Mendoza, J.; Campbell, J.F.; Throne, J.E. Influence of age, mating status, sex, quantity of food, and long-term food deprivation on red flour beetle (Coleoptera: Tenebrionidae) flight initiation. J. Econ. Entomol. 2011, 104, 2078-2086. [CrossRef] [PubMed]

61. Collins, D.A.; Cook, D.A. Laboratory studies evaluating the efficacy of diatomaceous earths, on treated surfaces, against stored-product insect and mite pests. J. Stored Prod. Res. 2006, 42, 51-60. [CrossRef]

62. Athanassiou, C.G.; Kavallieratos, N.G.; Boukouvala, M.C.; Mavroforos, M.E.; Kontodimas, D.C. Efficacy of alpha-cypermethrin and thiamathoxam against Trogoderma granarium Everts (Coleoptera: Dermestidae) and Tenebrio molitor L. (Coleoptera: Tenebrionidae) on concrete. J. Stored Prod. Res. 2015, 62, 101-107. [CrossRef] 
63. Ghimire, M.N.; Myers, S.W.; Arthur, F.H.; Phillips, T.W. Susceptibility of Trogoderma granarium Everts and Trogoderma inclusum LeConte (Coleoptera: Dermestidae) to residual contact insecticides. J. Stored Prod. Res. 2017, 72, 75-82. [CrossRef]

64. Skourti, A.; Kavallieratos, N.G.; Papanikolaou, N.E. How is fitness of Tribolium castaneum (Herbst) (Coleoptera: Tenebrionidae) affected when different developmental stages are exposed to chlorfenapyr? Insects 2020, 11, 542. [CrossRef] [PubMed] 